\title{
SPERMIATION AND SPERM TRANSPORT IN PASSERINE BIRDS
}

\author{
A. L. A. MIDDLETON \\ Department of Zoology, University of Guelph, \\ Guelph, Ontario, Canada
}

(Received 29th August 1973)

\begin{abstract}
Summary. The testes and seminal sacs of thirty European goldfinches and twenty-one canaries collected from specific nests at known phases of the nest cycle were histologically examined. Although no relationship between a characteristic stage of gonadal development and a specific phase of the nest cycle could be established, the histological findings suggested a relationship between the functioning of the seminal sac and the process of spermiation. The histological results are reported and a hypothetical mechanism for spermiation and sperm transport in passerine birds is described.
\end{abstract}

\section{INTRODUCTION}

In their study of the testicular cycle of the brown-headed cowbird (Molothrus ater), Scott \& Middleton (1968) reported the regular occurrence throughout the breeding season of an apparently post-breeding condition. Such testes, representing stages $6 / 7$ and 7 of the cycle, were characterized by enlarged seminiferous tubules in which the germinal epithelium was degenerating and the lumen was expanded and filled with variable quantities of spermatozoa and débris. Scott \& Middleton (1968) speculated on the significance of stages $6 / 7$ and 7 to the testicular cycle, but no definitive conclusion was reached. Middleton (1971) also reported the occurrence of stage 7 in the testicular cycle of the European goldfinch (Carduelis carduelis) but was again unable to determine its significance. Although the testicular cycles of many passerine species have now been described (Lofts \& Murton, 1968; Farner, 1973), stages 6/7 and 7 or their facsimiles have not been reported in other studies and the significance of their regular occurrence at the height of the breeding season remains obscure.

The initial aim of this study was to determine the relationship, if any, between stages of the testicular cycle and phases of nesting.

\section{MATERIALS AND METHODS}

As part of the gonadal study of the European goldfinch in Australia (Middleton, 1971), thirty male goldfinches were shot at nests for which the detailed history was known. All birds were collected at Wantirna, Victoria, Australia.

In 1969, a captive colony of canaries was established at the University of 
Guelph, Guelph, Ontario. The birds were housed in a room measuring $2.8 \mathrm{~m}$ $\times 3 \mathrm{~m}$ and individual pairs of canaries were placed in standard canary breeding cages measuring $26 \mathrm{~cm} \times 32 \mathrm{~cm} \times 58 \mathrm{~cm}$. The room was illuminated by four Westinghouse $40 \mathrm{~W}$, cool-light fluorescent tubes and eight $100 \mathrm{~W}$ incandescent lamps connected to a time switch with a dawn-dusk simulator. The photoperiod was adjusted weekly to approximate to the natural photoperiod. The birds were maintained on a diet of commercially prepared canary seed, grit and water.

During the breeding season, wire nest baskets, nest-liners and torn paper with excelsior packing were provided. Birds were paired in May 1969 and in March 1970 and were permitted to nest immediately (for details, see Keymer, 1967). Nine males in 1969 and twelve in 1970 were killed at selected phases of the nest cycle. In 1970, four unpaired males, housed in similar cages in the same room, were used as controls.

The testes and seminal sacs from the left side were dissected out and fixed for $24 \mathrm{hr}$ in Bouin's (goldfinches) or Allen's (canaries) fluid. Each organ was then cleared of excess tissue, blotted dry, weighed to the nearest $0.1 \mathrm{mg}$, embedded in paraffin wax and sectioned at $6 \mu \mathrm{m}$. Each organ was sectioned completely and sections from both apices and the intervening areas were selected and mounted on slides. Thus, sections which were representative of the entire organ were available for examination at any one time.

For both species, testes and seminal sacs from the right side were dissected out and fixed for $24 \mathrm{hr}$ in $10 \%$ formalin. Each organ was cleaned of excess tissue, weighed to the nearest $0.1 \mathrm{mg}$ and embedded in gelatin. Frozen sections were cut at $10 \mu \mathrm{m}$. Sections were mounted on slides and stained with Weigert's haematoxylin and Sudan IV.

As reported previously (Scott \& Middleton, 1968), no striking histological differences were detected between apical and central transverse sections of the testes. Thus, the reproductive condition of a testis could be evaluated equally well from examination of any section. In this study, a minimum of three sections selected at random from a slide were examined before that testis was assigned to a particular histological stage. The condition of each seminiferous tubule was assessed and if more than $50 \%$ of the tubules examined belonged to one specific stage of the testicular cycle, the testis was assigned to that stage. At no time in the study was any difficulty encountered in assessing the histological condition of a testis, since each testis examined had a clear majority of its tubules at a particular stage. The stages used in assessing testicular condition were those described by Scott \& Middleton (1968).

\section{RESULTS}

Stage 6 (breeding condition) was identified in forty-four $(80 \%$ ) birds including the controls, and occurred at each selected phase of the nesting cycle (Tables 1 and 2; Pl. 1, Fig. 1). The testes of three $(5.5 \%)$ birds were in a pre-breeding condition and those of eight $(14.5 \%)$, including one of the controls, were in a supposedly post-breeding condition (stages 6/7 and 7) (Tables 1 and 2; Pl. 1, Figs 2 and 3). Testes typical of stages $6 / 7$ and 7 occurred during each phase of 
Table 1. Mean testicular weight and histological condition of testes and seminal sacs of European goldfinches

\begin{tabular}{|c|c|c|c|c|c|c|}
\hline Nest stage & Sample size & $\begin{array}{c}\text { Mean combined } \\
\text { testicular wt } \\
(m g \pm S . E .)\end{array}$ & $\begin{array}{l}\text { Histologi } \\
\text { stage } \\
56\end{array}$ & & $\begin{array}{l}\text { Semin } \\
\text { Sperm. } \\
\text { present }\end{array}$ & $\begin{array}{l}\text { al sac } \\
\text { Sperm. } \\
\text { absent }\end{array}$ \\
\hline $\begin{array}{l}\text { Nest-building } \\
\text { Egg-laying } \\
\text { Incubating } \\
\text { Nestling } \\
\text { Fledgling }\end{array}$ & $\begin{array}{l}7 \\
4 \\
9 \\
7 \\
3^{*}\end{array}$ & $\begin{array}{r}96 \cdot 2 \pm 22 \cdot 0 \\
134 \cdot 2 \pm 15 \cdot 7 \\
133 \cdot 1 \pm 6 \cdot 6 \\
123 \cdot 0 \pm 16 \cdot 7 \\
127 \cdot 4\end{array}$ & $\begin{array}{r}1 \quad 5 \\
4 \\
9 \\
5 \\
3\end{array}$ & 2 & $\begin{array}{l}4 \\
3 \\
9 \\
6 \\
3\end{array}$ & $\frac{3}{1}$ \\
\hline
\end{tabular}

* Testis of one bird damaged; mean calculated for testes of two birds only.

Table 2. Mean testicular weight and histological condition of testes and seminal sacs of canaries

\begin{tabular}{|c|c|c|c|c|c|c|c|c|c|}
\hline \multirow{2}{*}{ Nest stage } & \multirow{2}{*}{ Sample size } & \multirow{2}{*}{$\begin{array}{c}\text { Mean combined } \\
\text { testicular wt } \\
(m g \pm S . E .)\end{array}$} & \multicolumn{5}{|c|}{$\begin{array}{l}\text { Histological } \\
\text { stage }\end{array}$} & \multicolumn{2}{|c|}{ Seminal sac } \\
\hline & & & 2 & $3-5$ & 6 & $6 / 7$ & 7 & present & $a b s e n t$ \\
\hline $\begin{array}{l}\text { Pairing } \\
\text { Nest-building } \\
\text { Egg-laying } \\
\text { Incubating } \\
\text { Nestling } \\
\text { Fledgling }\end{array}$ & $\begin{array}{l}5 \\
2 \\
5 \\
5 \\
1 \\
3\end{array}$ & $\begin{array}{l}114.4 \pm 34.3 \\
226.7 \pm 121.9 \\
167.7 \pm 57.3 \\
143.7 \pm 60.4 \\
195.7 \\
184.8 \pm 60.2\end{array}$ & 1 & & $\begin{array}{l}3 \\
2 \\
4 \\
4 \\
\\
2\end{array}$ & 1 & 1 & $\begin{array}{l}3 \\
2 \\
4 \\
4 \\
2\end{array}$ & $\begin{array}{l}\frac{2}{1} \\
1 \\
1 \\
2\end{array}$ \\
\hline Control & 4 & $153 \cdot 4 \pm 46 \cdot 2$ & & & 3 & & 1 & 3 & 1 \\
\hline
\end{tabular}

the nesting cycle with the exception of the egg-laying period. The seminal sacs of birds with stage 6 testes (Pl. 1, Fig. 4) had enlarged tubules filled with spermatozoa and the epithelium was in a varied condition (Middleton, 1972).

By contrast, birds with testes at stage $6 / 7$ had seminal sacs in which the tubular lumen was constricted and was devoid of spermatozoa (Tables 1 and 2; Pl. 2, Figs 5 to $8, \mathrm{Pl}$. 3, Figs 9 to 11 ).

Lipids were restricted to the Leydig cells within the interstitium of all stage 6 testes. In the stage 6/7 and stage 7 testes, however, lipids were observed within the Leydig cells of the interstitium and also within the germinal epithelium and the lumen of the seminiferous tubules (Pl. 3, Fig. 12).

\section{DISCUSSION}

In most studies of passerine gonadal cycles, full spermatogenesis (stage 6) is the characteristic stage of the testes during the breeding season, and $80 \%$ of the nesting male birds studied in this investigation had testes in this condition. Since stage 6 testes were collected from birds with nests at each of the phases selected for study, such testes were clearly not associated with any one specific phase of nesting.

Of the remaining birds, $14.5 \%$ had testes which were in an apparently postbreeding condition (stage 6/7 and 7). Scott \& Middleton (1968) reported a high incidence of stage $6 / 7$ and 7 testes during the breeding season in the brownheaded cowbird. Although they suggested such testes were in a post-breeding 
condition, Scott \& Middleton (1968) were not convinced that stages $6 / 7$ and 7 were truly indicative of the cessation of breeding. The results of this study show that stages $6 / 7$ and 7 occurred throughout the nesting cycle and were associated with each phase of nesting, with the exception of egg-laying (Tables 1 and 2). Thus, stages $6 / 7$ and 7 appear to be normal and integral stages in the testicular cycle of nesting passerine birds.

Histologically, stage $6 / 7$ and 7 testes are characterized by tubules in which the germinal epithelium is drastically disrupted and quantities of débris are evident (Pl. I, Figs 2 and 3). Such testes also show the presence of lipid-sensitive material within the seminiferous tubules, which is indicative of a post-breeding condition in birds (Marshall, 1961 ; Lofts \& Murton, 1968) and reptiles (Lofts, Phillips \& Tam, 1966).

In experimenting with factors related to spermatokinesis (spermiogenesis) in the house sparrow (Passer domesticus), Frantz (1958) observed a stage similar to stage 7 . He showed that an accumulation of fluid caused distention of the seminiferous tubules with the subsequent disruption of the germinal epithelium and the release of spermatozoa from the Sertoli cells. Although he could not explain the mechanism for the accumulation of fluid, he suggested that spermatokinesis was effected by a hormone-induced increase in the permeability of cell membranes to water. Barack (1968) described a histological condition in the testes of the mouse, which was similar to stage 7 in passerine birds. This stage appeared after the ligation of the ductuli efferentes and was characterized by dilatation of the seminiferous tubules accompanied by various degrees of shedding and/or degeneration of the germinal epithelium. Studies of spermiation

\section{EXPLANATION OF PLATES}

PLATE 1

FIG. 1. Canary testis in breeding condition (stage 6) showing uniformly arranged sperm bundles. H \& E.

FIG. 2. Ganary testis undergoing spermiogenesis (stage 6/7). Fluid accumulation is causing disruption of the germinal epithelium $\mathrm{H} \& \mathrm{E}$.

FIG. 3. Ganary testis undergoing spermiogenesis (stage 7). Fluid accumulation has caused distension of the seminiferous tubules and drastic disruption of the germinal epithelium. $\mathbf{H} \& \mathrm{E}$.

Fig. 4. Canary seminal sac corresponding with testis shown in Fig. 1. Tubules are open and spermatozoa are abundant. $\mathrm{H} \& \mathrm{E}$.

PLATE 2

Fig. 5. Ganary seminal sac to correspond with testis shown in Pl, 1, Fig. 3. Tubules are constricted and spermatozoa absent. H \& E.

FiG. 6. Low power configuration of seminal sac shown in Fig. 5.

FIG. 7. Canary testis undergoing spermiogenesis (stage 6/7). H \& E.

Fig. 8. Seminal sac corresponding with testis shown in Fig. 7. $\mathrm{H} \& \mathrm{E}$.

PLATE 3

FIG. 9. Seminal sac corresponding with testis shown in P1. 1, Fig. 2. H \& E.

Frg. 10. European goldfinch testis undergoing spermiation (stage 6/7). H \& E.

FIG. 11. Seminal sac corresponding with testis shown in Fig. 10. H \& E.

FIG. 12. Section of frozen canary testis showing presence of lipid in seminiferous tubule and interstitium. Right testis corresponding to left testis shown in PI. 2, Fig. 7. Sudan IV. 
PLATE 1
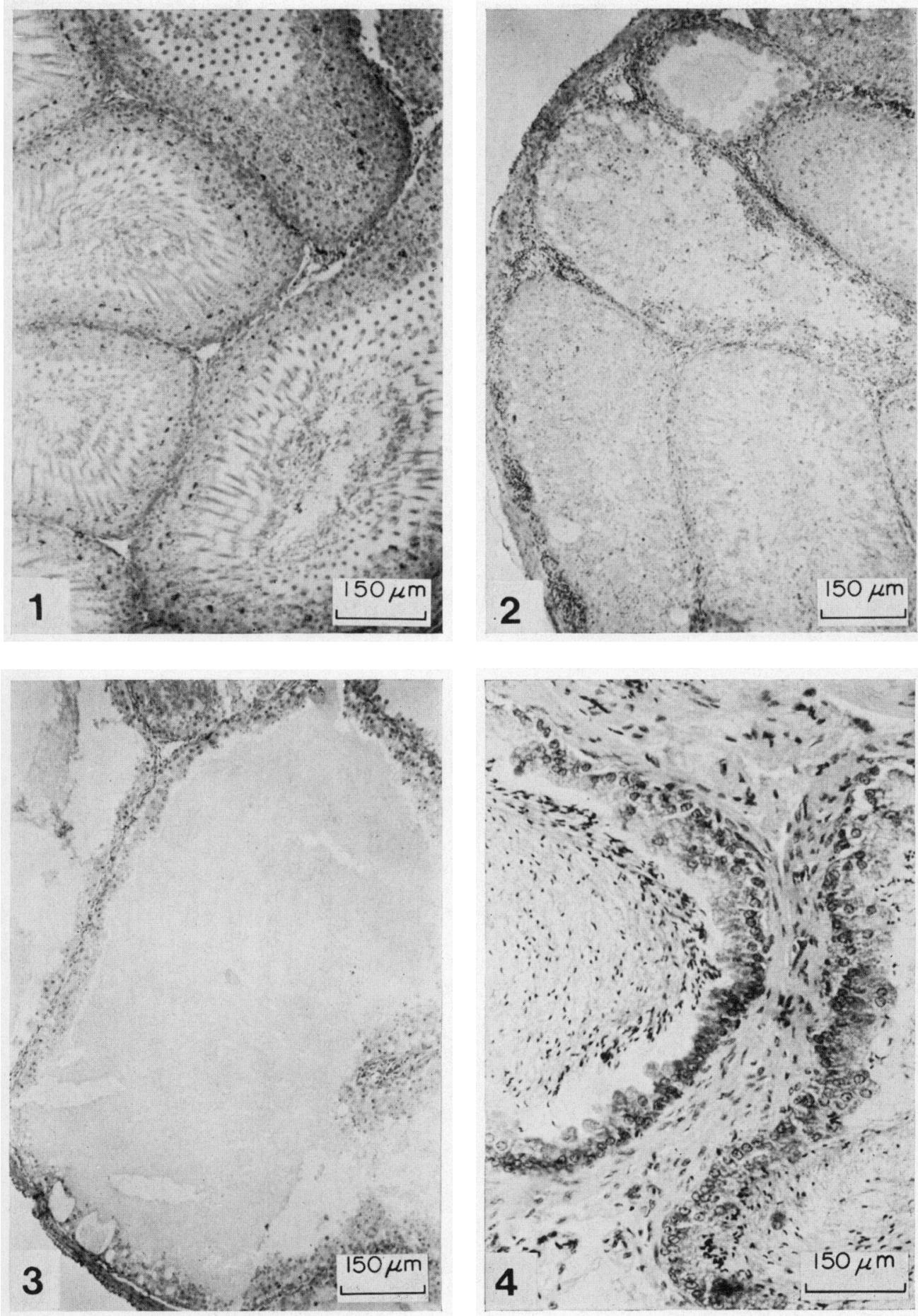

(Facing p. 34) 
PLATE 2
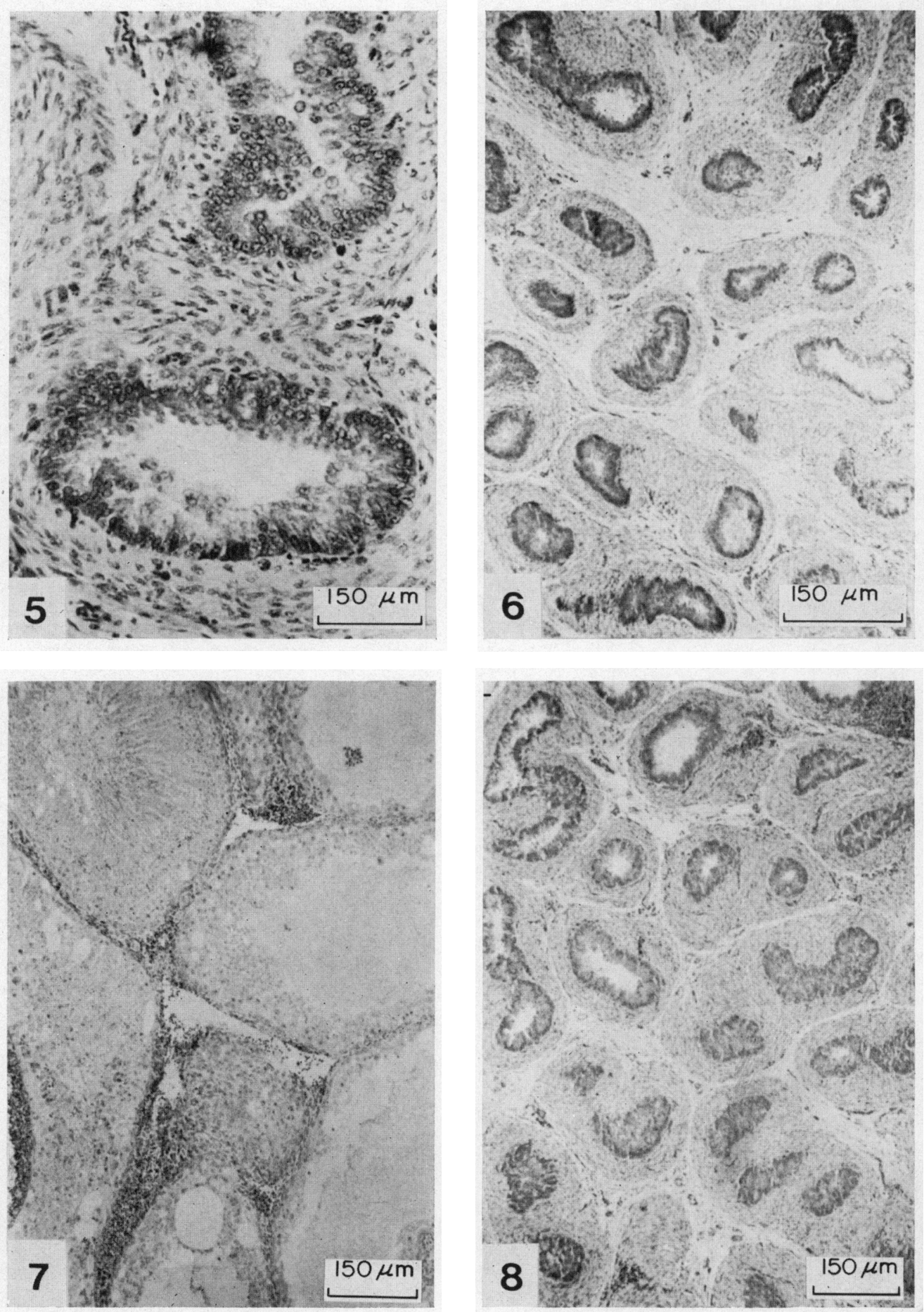
PLATE 3
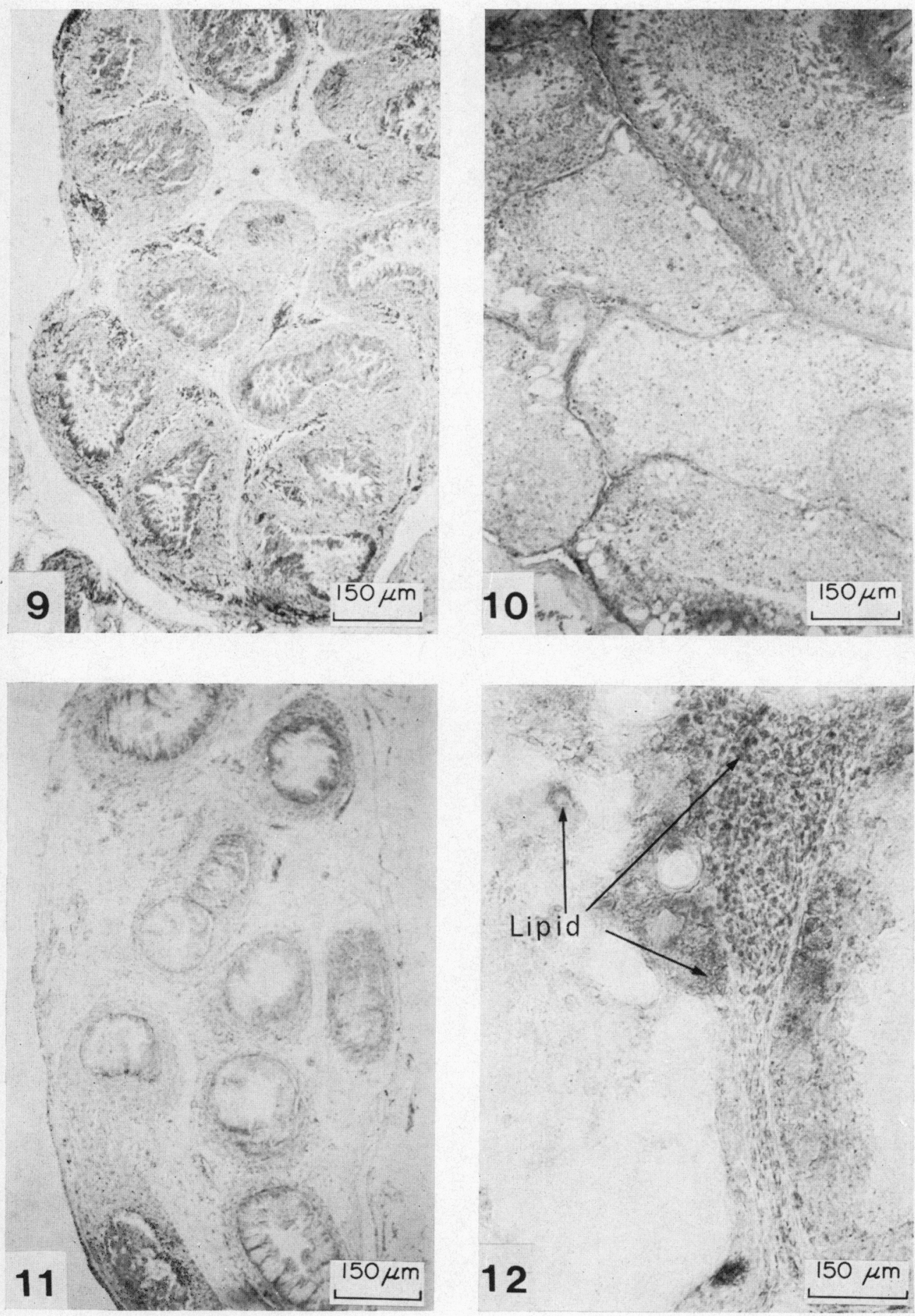
in fish (Yamazaki \& Donaldson, 1969), amphibians (Burgos \& Vitale, 1964; Burgos \& Vitale-Calpe, 1967) and mammals (Setchell, 1968; Vitale-Calpe \& Burgos, 1970) have shown that spermiation is accompanied by increased fluid within the testes. Various authors (Burgos \& Vitale-Calpe, 1967; Setchell, 1968; Fawcett \& Phillips, 1969; Vitale-Calpe \& Burgos, 1970) suggest that, under the influence of $\mathrm{LH}$, water enters the endoplasmic reticulum of the Sertoli cells and gradually accumulates in the apical cytoplasm of the cells. Finally, the water passes into the lumen of the seminiferous tubules carrying with it the liberated spermatozoa and cell débris.

In the light of the preceding discussion and the results of this study, the mechanism of spermiation in passerine birds becomes apparent. Testes at stages $6 / 7$ and 7 of the testicular cycle are accompanied by seminal sacs, the tubules of which are constricted and devoid of spermatozoa. It seems possible that, under the appropriate hormonal stimulus, the smooth muscles surrounding the tubules of the seminal sac and ductus deferens constrict. Simultaneously, the fluid content of the Sertoli cells increases under the influence of $\mathrm{LH}$, and eventually the fluid is released into the lumen of the seminiferous tubule with the sperm cells. Since the tubules of the seminal sac and ductus deferens are constricted, however, the fluid cannot escape from the testes and gradually accumulates. Histologically, such testes would resemble stages $6 / 7$ and 7 of the cycle. As the process continues, free spermatozoa accumulate and hydrostatic pressure within the testes continues to increase. Eventually, the relaxation of the smooth muscle of the deferent ducts and seminal sacs permits a sudden flushing of the testes, thus effecting passage of the mature spermatozoa to the seminal sacs for immediate use or storage (Middleton, 1972). Following spermiation, the surviving spermatogonia are stimulated to further cell division and a new wave of spermatogenesis begins. Fertilizing ability is not lost during this period, however, since viable spermatozoa are available within the seminal sacs (Middleton, 1972).

If the significance of stage 7 is accepted as described, the frequent occurrence of stage 7 in the studies of Scott \& Middleton (1968) and Middleton (1971) suggests that spermiation occurs regularly throughout the breeding season. Thus, a spermatogenic cycle may occur in passerine birds as in other vertebrates (Barack, 1968; Kennelly, 1972). Although no data are available on the duration of this cycle in passerine birds, Hamner (1968) has shown that testicular recrudescence within individual birds can occur in a matter of days. Frantz (1958) showed maximum fluid distention of the testes to occur within 3 to $4 \mathrm{hr}$ of water immersion or hormonal injection, and the sloughing process was well advanced after $4 \mathrm{hr}$. These data suggest that the passerine spermatogenic cycle may occupy a few days only and that spermiation may occur within the space of a few hours.

Lipids are normally found in the testis at all stages of the spermatogenic cycle (Johnson, 1970), but the presence of massive quantities of lipids within the seminiferous tubules of birds has generally been accepted to indicate cessation of reproductive activity and the start of the photo-refractory period (Marshall, 1961; Lofts \& Murton, 1968). Tubular lipids are known to increase in abundance if spermatogenesis is impaired (Johnson, 1970), or parts of the testis become devoid of spermatozoa and testicular fluids (Turner \& Johnson, 1971). Since spermiation, as described in this paper, disrupts spermatogenesis, and a 
loss of testicular fluids occurs at evacuation, the accumulation of tubular lipids may be an integral part of spermiation. In the present study, lipids were found in the testes of actively nesting birds. Thus, the presence of abundant lipid within the seminiferous tubules of passerine birds may not necessarily indicate cessation of spermatogenesis as is generally accepted.

When tubular lipids are identified within the testis, particular attention should be paid to the lipid content of the interstitial Leydig cells. If such cells show the presence of lipid droplets, they are still actively producing testosterone and the testis is still in breeding condition. If lipid droplets cannot be detected, the Leydig cells are approaching, or have reached, seasonal exhaustion and the testis may have lost its capacity to undergo further spermatogenic cycles. Under such circumstances, the massive tubular steatogenesis, which often accompanies stages 8 and 9 of the testicular cycle, may be truly indicative of a post-breeding photorefractory condition.

\section{AGKNOWLEDGMENTS}

Thanks are expressed to Mr David Noonan of Wantirna, Victoria, for placing his apple orchard at my disposal as a collecting site; to my colleague, $\mathrm{Mr}$ Fred Ramprashad, for assistance with the photographs and criticism of the manuscript, and to the late Professor A. J. Marshall of Monash University for providing funds and facilities while $\mathrm{I}$ was a student in his department. Financial support was also provided by the National Research Council of Canada through grant No. A 3911.

\section{REFERENCES}

BARAcK, B. M. (1968) Transport of spermatozoa from seminiferous tubules to epididymis in the mouse: a histological and quantitative study. F. Reprod. Fert. 16, 35.

Burgos, M. H. \& Vitale, R. E. (1964) The mechanism of the release of spermatozoa. Proc. 2nd Int. Congr. Endocrinol., London, 1964, p. 1299.

Burgos, M. H. \& Vitale-Calpe, R. (1967) The mechanism of spermiation in the toad. Am. F. Anat. $120,227$.

FARner, D. S. (Ed.) (1973) Breeding Biology of Birds. Natn. Acad. Sci., Washington, D.C.

FAwCETT, D. W. \& Phillips, D. M. (1969) Observations on the release of spermatozoa and on changes in the head during passage through the epididymis. F. Reprod. Fert., Suppl. 6, 405.

Frantz, W. L. (1958) Some factors effecting spermatokinesis in the testes of the house sparrow (Passer domesticus $)$. Endocrinology, 63, 507.

Hamner, W. N. (1968) The photorefractory period of the house finch. Ecology, 49, 211.

Johnson, A. D. (1970) Testicular lipids. In The Testis, Vol. II, Ch. 4. Eds. A. D. Johnson, W. R. Gomes and N. L. VanDemark. Academic Press, New York and London.

KENNELLY, J.J. (1972) Coyote reproduction. I. The duration of the spermatogenic cycle and epididymal sperm transport. F. Reprod. Fert. 31, 163.

KEYMER, I. F. (1967) The canary and the budgerigar. In The U.F.A.W. Handbook on the Care and Management of Laboratory Animals, Ch. 48. Churchill Livingstone, Edinburgh and London.

Lorts, B. \& MURTON, R. K. (1968) Photoperiodic and physiological adaptations regulating avian breeding cycles and their ecological significance. F. Zool., Lond. 155, 327.

Lorts, B., Phillips, J. G. \& TAM, W. H. (1966) Seasonal changes in the testis of the cobra Naja naja (Linn.). Gen. Eै compar. Endocr. 6, 466.

Marshall, A. J. (1961) Breeding seasons and migration. In Biology and Comparative Physiology of Birds, Ch. 21. Ed. A. J. Marshall. Academic Press, New York and London.

Middleton, A. L. A. (1971) The gonadal cycle of the goldfinch in south-eastern Australia. Emu, 71, 159.

Mmdeton, A. L. A. (1972) The structure and possible function of the avian seminal sac. Condor, 74, 185. 
Scott, D. M. \& Middezton, A. L. A. (1968) The annual testicular cycle of the brown-headed cowbird (Molothrus ater). Can. F. Zool. 46, 77.

SETCHELL, B. P. (1968) Testicular blood supply, lymphatic drainage and secretion of fluid. In The Testis, Vol. I, Ch. 3. Eds. A. D. Johnson, W. R. Gomes and N. L. VanDemark. Academic Press, New York and London.

TURner, P. G. \& Johnson, A. D. (1971) Epididymal lipid of the rat with and without testicular contribution. J. Reprod. Fert. 27, 249.

Vitale-Galpe, R. \& Burgos, M. H. (1970) The mechanism of spermiation in the hamster. I. Ultrastructure of spontaneous spermiation. F. Ultrastruct. Res. 31, 381.

YAMAZAKI, F. \& Donaldson, E. M. (1969) Involvement of gonadotropin and steriod hormones in the spermiation of the goldfish (Carassius auratus). Gen. E compar. Endocr. 12, 491. 